At the same time we must recognize the fact that in recent years not only has the production of wealth greatly increased, but also this wealth has reached the people, and represents a triumph of democratic economy. The New York Sun recently offered some statistics, of which I quote a part : In 1900 there were in the United States about 1,000,000 telephones; now there are $20,400,000$. In 1900 there were 8,000 automobiles; in 1941 there are 25,000,000. In 1920 there were only 1,000 radio sets; in 1941 there are $43,000,000$. In 1910 there were $16,372,000$ savings accounts ; in 1941 there are 46,000,000.

These gains are enormous, yet not without their disadvantages. In the United States nearly a hundred thousand persons die from accidents each year, a large proportion due to incompetent handling of automobiles. The radio brings us wisdom, but more trash. Thus we have to learn to enjoy and profit by our blessings, avoiding their misuse. Here we have a clearly defined programme, and we can carry it forward without waiting for the end of the War. Among reasonable people it should meet with no hostility, but it does imply willingness to co-operate, and a certain degree of courage and faith. I can believe that very many of those who are now our enemies would be glad to join with us in the endeavour, once they are convinced that we are sincere and unafraid.

University of Colorado, Boulder, Colorado.

\section{A Scientific Press Bureau}

The second editorial article in Nature of August 30, "Physics and the Future", remarks how remote is science to the majority of citizens. As never before, pure and applied science to-day plays an essential part in affairs, and it has recently been said that scientific development can make good in a very short time the material wastage and set-backs of this War. But it is only occasionally, as when 'Radiolocation' was announced, that the average citizen realizes that science is not entirely a means of producing more and more terrible weapons of destruction. The scientific attitude applied to our post-war problems, we believe, can rid civilization of recurrent wars and economic chaos. If we admit the ideal of democracy, the power of science to accomplish these ends must depend upon the public acceptance of science as a desirable thing.

Now how does the average citizen learn of the work of science? We find in the Manchester Guardian and The Times excellent accounts of new developments, but the mass-circulation newspapers almost without exception ignore scientific news but for occasional garbled items of a sensational nature, or comic strips of the "Buck Ryan and his Space Ship" type.

In the United States, newspaper readers are better served. Natural science editors contribute special and weekly articles in most of the large papers, and Science Service, directed by Watson Davis, publishes the weekly "Science News-Letter" which is frequently quoted by the Press.

While planning for the future, the representatives of science in Great Britain must admit the question of public relations in the post-war period, otherwise science may not attain the recognition necessary for it to contribute fully towards a better world. Instead, antagonism might grow up among those who know only of the inventions that have been misapplied in war and in commercial exploitation.

What is required now is a 'set of blue-prints' for a future Scientific Press Bureau, supported by the scientific societies and engineering institutions and staffed by experienced journalists. Bold in conception and vigorous in its policy, it must bring to the man in the street, through his newspaper, accurate and balanced knowledge of the work, aims and achievements of science and the technical arts.
99 Marshalswick Lane,
D. L. Johnston. St. Albans,

Herts. Aug. 31 .

\section{Plankton as a Source of Food}

IN reply to the latest communication under this heading ${ }^{1}$, I would like briefly to recall $(\alpha)$ the common agricultural practice of green manuring ${ }^{2}$ in which often the only obvious addition to the land is of 'carbon's though the benefit to future crops is undeniable ${ }^{4}$, (b) the importance of freshwater algæ as soil surfacebinders ${ }^{5}$ even if the addition of potential humus is small, (c) the facts that many algæ are notoriously rich in vitamins ${ }^{8}$ and are now known to contain growth-substances ${ }^{7}$ in such amounts as might conceivably be absorbed from the soil by seeds ${ }^{8}$ and roots $^{\theta}$ and have a formative and growth-promoting action upon various organs of vegetable plants ${ }^{10}$, (d) that the exact manurial and other treatment can further condition the vitamin content and growth and robustness of a crop for reasons not yet understood $^{4}$, (e) the ubiquity and usual wastage of the human system as a source of combined nitrogen and phosphorus as well as of auxins ${ }^{10}$, and $(f)$ that Cyanophyceæ capable of fixing nitrogen can be grown in mineral solutions as well as on or near the surface of soil ${ }^{11}$, while the presence of other algæ increases nitrogen-fixation by bacteria $^{5}$; on the other hand it is often wasteful and may be harmful to add nitrates and ammonium salts to soils that have to be watered ${ }^{12}$.

In my previous communication ${ }^{13}$ I did not, nor do I now, contend that any (or even several together, so far as they are applicable) of these or related matters that may be concerned with plant nutrition via watering will actually benefit the growth and production of vegetable crops to an appreciable degree ; my object was merely to suggest a mode of practical application after pointing out such a possibility, which, I maintain, should be fully investigated by means of controlled field experiments in proper bulk.

Department of Botany,

University of Oxford. Sept. 13.

1 Naț̣Re, 148, 314 (September 13, 1941).

${ }^{2}$ Imperial Bureau of Soil Science, Technical Communication No. 22.

${ }^{3}$ Russell, "Soil Conditions and Plant Growth", 7th ed., London (1937).

"Jenkins, "Organic Manures", Imperial Bureau of Soil Sciense, Technical Communication No. 33 (1935).

"Fritsch, "The Rôle of the Terrestrial Alga in Nature", Essays in Geobotany ..., 195, California (1936).

"Tilden, "The Algæ and their Life Relations", London (1935).

' van Overbeek, Bot. Gaz., 101, 940 (1940).

${ }^{8}$ Croxall and Ogilvie, J. Pomol. and Hort. Sci., 17, 362 (1940).

- Hitcheock and Zimmerman, Contrib. Boyce Thompson Inst., 7, 447 (1935) ; Pfahler, Jahrb. wiss. Bot., 86, 675 (1938).

${ }^{10}$ Went and Thimann, "Phytohormones", New York (1937); Meyer and Anderson, "Plant Physiology", London (1940).

${ }^{11}$ Nature, 142, 878 (1938).

12 Barker, "The Use of Fertilizers", London (1935).

${ }^{13}$ NATURE, 148, 143 (1941). 